\title{
Assessing Stakeholders' Views of Tourism Policy in Prince Edward County
}

\author{
Rachel Dodds \\ Assistant Professor, Ted Rogers School of Hospitality \& Tourism Management \\ Ryerson University, 350 Victoria Street, Toronto, ON, M5B 2K3 \\ Tel: 1-416-979-5000 x 7227 E-mail: r2dodds@ryerson.ca
}

Soyoung Ko

Ted Rogers School of Hospitality \& Tourism Management

Ryerson University, 350 Victoria Street, Toronto, ON, M5B 2K3

E-mail: Soyoung2.ko@ryerson.ca

Received: March 21, 2012 Accepted: April 11, 2012 Published: May 14, 2012

doi:10.5296/emsd.v1i1.1624

URL: http://dx.doi.org/10.5296/emsd.v1i1.1624

\begin{abstract}
Prince Edward County, located in Ontario, Canada, is both a rural destination and an island. The destination, known familiarly as PEC, is fast becoming the newest winery destination in Ontario and faces the challenge of developing a tourism industry that is financially, socially, and environmentally sustainable. Like many other islands or rural areas, Prince Edward County is isolated and vulnerable to pressures from development and other human activities and sustainable development in PEC requires strategic and careful tourism planning.

To support the viable development of a tourist destination while improving the regional quality of life, tourism policies must be forward-looking and satisfy the needs of multiple stakeholders. This allows more efficient and acceptable policy implementation as the policies are inclusive and cohesive. This study assesses current stakeholder perceptions of current tourism development and future tourism planning in PEC. The findings revealed that although the majority of the stakeholders agree with the importance of tourism development, many feel there are issues not being addressed by the county and are unhappy with the current direction of tourism development.
\end{abstract}

Keywords: Prince Edward County, tourism development, planning, stakeholder, sustainability 


\section{Introduction}

Many island or rural destinations are recognizing the potential contribution of tourism as a strategy for a sustainable livelihood. With a slower pace of life compared to their mainland and urban counterparts, rural island communities traditionally have been supporting themselves with livelihood opportunities such as agriculture, logging, fishing, and mining. However, this paradigm is changing as many destinations, especially those with rural communities, have experienced a decline in these traditional livelihoods and turned to tourism in an effort to diversify the livelihood opportunities (Lockhart, 1997). The insularity of these areas motivates tourists to pursue unique experiences away from their busy routine. People travel to these remote locations for their rich and diverse cultures, unique environment, and isolated communities (Lim \& Cooper, 2009).

Since most tourism services are resource-intensive, destinations are particularly susceptible to significant environmental impacts resulting from the overuse of resources or uncontrolled development (Dodds, 2007). For these reasons, sustainable development requires strategic and careful tourism planning. Integration of sustainability into tourism development planning is often recognized as a solution to the negative social and environmental issues associated with the rapid growth of tourism (Dodds, 2007). The absence of appropriate planning can lead to a strain on public services and the environment, conflicts between stakeholders, increased costs of conflict resolution, and decreased support from the community (Marcouiller, 1997; Yuksel, Bramwell, \& Yuksel, 1999). Strategically well-planned tourism, however, can provide a community with both economic benefits and preservation of the destination (Edgell, Allen, Smith, \& Swanson, 2008). Attempting to form this linkage is a significant step towards sustainable development, especially links to agriculture by creating regional products (Duim \& Caalder, 2004) to attract visitors.

Tourism and regional development are closely related and interdependent on each other. Therefore, the policies created by the regional and local authorities are integral for the success of both tourism and regional development (Gülcan, Kustepeli, \& Akgüngör, 2009). To support the viable development of a tourist destination while improving the regional quality of life, these policies must be forward-looking and satisfy the needs of multiple stakeholders. The stakeholders affected by tourism include environmental groups, business interests, public authorities and community groups (Medeiros de Araujo \& Bramwell, 1999). Tourism is especially dependent upon and affects the natural resources of the area; thus, management requires "a careful balance between the needs of the host community and the needs of the tourism industry" (Edgell, et al., 2008, p.195).

It is generally accepted that stakeholders should be involved and monitored during the tourism planning and implementation processes if tourism is to be sustainable and long-term (Medeiros de Araujo \& Bramwell, 1999; Yuksel, et al, 1999; Simpson, 2001), and involving those affected by tourism development would be politically responsible (Bramwell \& Sharman, 1999). Previous literature discusses many benefits in involving the stakeholders when creating tourism policy. Sustainable development requires creating a consensus from conflicting stakeholder viewpoints (Simpson, 2001) which can increase the acceptance and 
quality of the plan (Medeiros de Araujo \& Bramwell, 1999). Resolving these conflicts during the planning stage can reduce the cost of their resolution in the long term and can improve the implementation of the plan (Bramwell \& Sharman, 1999). This allows more efficient and acceptable policy implementation as the policies are inclusive and cohesive.

According to Theobald (2005), sustainability can be reached only when stakeholder groups share goals and when shared meaning and goals among destination stakeholders are achieved. Tourism should not be in conflict with the communities' activities; rather, tourism should fit into the existing situation as a complementary activity, contributing to economic diversification and forging positive linkages with existing forms of production (Tao \& Wall, 2008).

"Tourism has the potential to empower communities and the sustainable tourism agenda needs to focus on how to bring this about... understanding tourists and tourism processes is the first stage to empowering the local community to make informed and appropriate decisions about their tourism development (Cole, 2006: 630).”

It is important for the local community (as well as other stakeholders) to understand tourists and tourism practices before they participate in deciding and agreeing on a tourism development plan. This paper, therefore seeks to understand stakeholder views in a destination to assess viewpoints surrounding tourism policy and planning.

\section{Background of Prince Edward County (PEC)}

Prince Edward County, situated in southeastern Ontario, Canada, is a growing tourist destination. It is also an island, as it is located in Lake Ontario and connected to the mainland by bridges. The destination, known familiarly as PEC, faces the challenge of developing a tourism industry that is financially, socially, and environmentally sustainable. Like many other rural and island destinations, Prince Edward County is isolated and vulnerable to pressures from development and other human activities. Prince Edward County is also fast becoming the newest winery destination in Ontario. It is transforming its traditional agriculture and small town charm to meet the changing needs of visitors. This small rural county attracts travelers seeking a unique tourist experience from its rich cultural and natural heritage.

Prince Edward County is a destination with 1,048 square kilometres of land space and 800 kilometres of shoreline. 'The County', whose main town is Picton, is situated in south-eastern Ontario, Canada, and is located in the province's "golden triangle", the heart of Canada's population belt formed by Toronto, Ottawa, and Montreal, and is only a few hours from each city and is also close to an entry point from the U.S (see figure 1). This small rural county with rich cultural and natural heritage is a home to a population of about 25,500 residents. Its primary livelihood is traditional agriculture with 770 farms that produce predominantly dairy, beef, grains and oilseeds. Recently, PEC saw an increasing number of diversified forms of agriculture such as viticulture and organic farming, and other tourism-related activities and businesses being developed (Prince Edward County, 2007). 


\section{MInstitute Macrothink}

\subsection{Economy in Prince Edward County}

The four pillars of PEC's economy are identified by PEC Economic Development in the County of Prince Edward Official Plan and comprise of agriculture, tourism, commerce and industry, and arts, culture, and heritage (Prince Edward County, 2008; Ainsley \& Associates, 2006). PEC's agricultural industry accounts for nine percent of the county's employment and generated $\$ 76,727,274$ in revenues from its 770 farms in 2006. In the last five years there has been a shift in the agricultural offerings in PEC as the number of wineries in the county grew from 15 wineries in 2005 to 26 in 2010.

Tourism is one of the main industries in PEC today. The county's combination of natural, historical, cultural, and culinary attractions draws more than 440,000 visitors annually who bring an estimated spending of $\$ 65.4$ million per year (Prince Edward County, 2008). Among natural attractions, Sandbanks Provincial Park is the most popular place in the county, where visitors can enjoy a variety of outdoor activities. Along with wineries, there are also two breweries, 49 dining establishments, high-end specialty stores (antiques, boutiques and artistry), and farmer's markets (Prince Edward County, 2008). Being Ontario's newest wine region and culinary destination, the region attracts tourists with its top chefs and organic cuisine and hosts up to 29 festivals per year. PEC currently promotes three different tourism activities: culinary, eco, and outdoor tourism. Culinary tourism promotes the 'Taste Trail' of the county to the food-centric tourists, introducing winery tours, local farm products, artisanal cheeses, ciders, and craft beers. Ecotourism in the county promotes its natural areas including valleys, vineyards, coves, bays, a bird observatory, and the popular provincial park. Outdoor tourism initiatives market sun, sand, small town charm, fishing, boating, sailing, windsurfing, golfing, and birding.

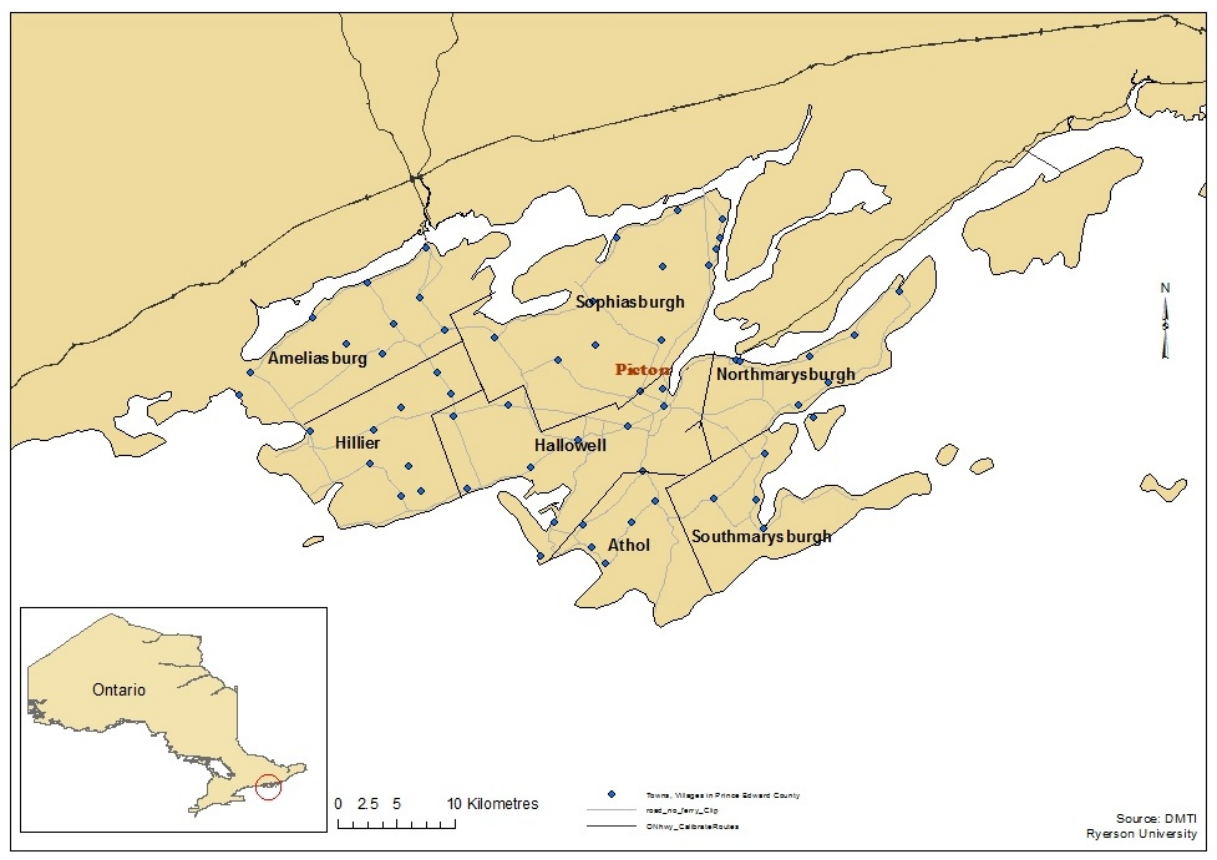

Figure 1. Prince Edward County Map 
Many creative individuals have relocated to PEC to pursue the quality of life and the local artistic ambiance, raising the number of residents employed in the arts dramatically. There are over one hundred independent artists and 53 galleries with three gallery tours, artistic institutions such as the Regent Theatre, and festivals such as the Jazz Festival. This is seen as a separate sector of arts, culture and heritage but is closely tied to tourism.

Manufacturing and value-added industries contribute to PEC's economic viability, including cement production, food processing, and kayak and canoe production. The commerce and industry sectors play a role in the region's economic success and vitality as they are responsible for 11 per cent of total employment in the county. An international cement factory, Essroc, represents a major employer which takes advantage of natural resources and the area's deep-water harbour; food processing for cheeses, vegetables, and meats has been supported by the county's agricultural base, and Canada's largest kayak and canoe manufacturer has relocated to a waterfront factory in the county.

Prince Edward County is currently redefining its economy with wineries, artisanal industries, organic and specialty farms, and a multifaceted arts community. Tourism, one of the four main pillars, is currently being developed and is contributing significantly to the county's economy and the viability of the residents' livelihood heavily depends on the future direction of this area. Tourism has grown substantially but so have the impacts. Water shortages, pollution, increased tourism numbers causing crowding and a decreasing labour pool are issues that residents and visitors must face. Therefore, PEC is at a critical stage and must assess and evaluate whether the future tourism development will provide a sustainable livelihood for all stakeholders in the county. The county's community representatives seek to preserve the area's traditional qualities while accommodating growth among the communities within. These concerns are addressed through the PEC's official development plan.

\subsection{Planning in Prince Edward County}

The County of Prince Edward Official Plan was adopted in 1993 and approved in 1998. It detailed the development policy in the county to the year 2021. It was based on extensive background studies and primary research including focus sessions, questionnaires, and public meetings to ensure that the plans represented what the community wanted. It covers development strategies of various economic sectors including agriculture, tourism, service, and light industry. The Official Plan is currently under review for an update. As part of the review process, PEC retained Class Consultants from Ryerson University's Urban Planning Department in 2009 in an effort to analyze the current status of its creative industries and to receive recommendations on how to nurture those industries while preserving the unique rural character of the county. Cultivating Rural Creativity is the report by Class Consultants in collaboration with primary contacts in the Prince Edward County Planning and Economic Development Departments (Ryerson University \& PEC, 2009). The county also consulted the Department of Geography at Queen's University, who addressed strategies for innovative, creative, and sustainable development in the county in its report Growing the Creative-Rural Economy in Prince Edward County (2008).

Although all three reports discuss plans and strategies for sustainably developing the county, there are significant variations in terms of the focuses of development areas and directions for 


\section{Macrothink}

viable community growth. The Official Plan suggests that for economic viability, agriculture, tourism, service, and light industry should be balanced. It also emphasizes to protect, enhance, and promote PEC's historical, cultural, and natural attractions while controlling development. Its focus on sustainable development through environmental protection also differentiates it from the two other plans. Cultivating Rural Creativity mainly addresses and promotes retaining and enhancing innovative agriculture while directing growth to areas that do not affect prime agricultural land. It links the agricultural strengths of the community with agro-tourism as farmers are increasingly diversifying their farms to preserve their livelihoods. Finally, the strategy titled Growing the Creative-Rural Economy proposes strategies based on current challenges and opportunities that the county possesses. For the potential direction of sustainable economic development in the county, it recommends attracting people in creative and innovative occupations and encourages overall development in arts, heritage, culture, wine and cuisine, and nature. Including the three aforementioned reports, there have been a number of plans and strategies to discuss future recommendations for the county; however, few outline what the views of the stakeholders in the county are. Therefore, the purpose of this research is to determine stakeholders' views within the county regarding current tourism development and future tourism planning.

\section{Research Methods}

In order to assess current stakeholder perceptions of current tourism development and future tourism planning, a questionnaire was distributed to stakeholders in PEC. The sampling frame for this study consisted of stakeholders who belong to one of the predefined types of organizations: accommodation, tour provider/attraction, gallery/craft/gift shop, food or beverage service/restaurant, winery/cider brewers, agriculture, non-tourism business, government, marketing/industry association, and non-government organization. The list of stakeholders was collected from various government and commercial websites including the Prince Edward County Chamber of Tourism \& Commerce website (see figure 2).

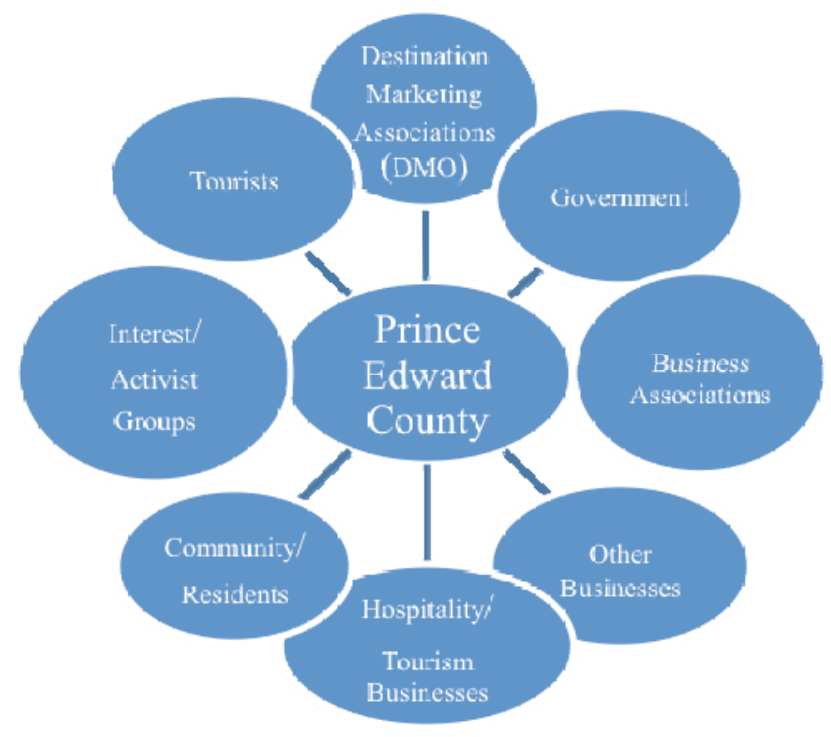

Figure 2. Stakeholder Map 
The 21-question survey included a combination of closed, open-ended, and multiple choice questions, and 5-point Likert-type scale questions. The survey was divided into three sections. The first section profiles the stakeholders and identifies their perception of the tourism development status by asking about the respondent, their type of business and its seasonality, and the importance of tourism development to them. The second section included questions to gain unprompted responses to current issues of tourism development. The last section then asked for their opinion on the current tourism development plans and its future direction, and finally recommendations for tourism development. The final version of the survey was sent to the sample test group of three individuals who live in the county but work in (rather than own) a tourism business and their feedback was used to finalize the survey design.

A total of 224 online surveys were distributed in February 2011 through a web-based survey solution provider and 59 of them were returned; however, an additional 63 surveys were collected through a web link to the survey that was posted by one of the respondents on a local business association website. Among the 122 surveys collected, two questionnaires were excluded, one not qualified to be a predefined stakeholder and the other with incomplete data. This resulted in a final sample of 120. Data was then tabulated using IBM's Statistical Package for the Social Sciences (SPSS). Due to the low frequency of some choices in the 5-point Likert-type scale questions, most of the scale questions were aggregated to 3-point Likert-type scale questions so that each point in the scale can represent the responses in a more comprehensive way. Frequencies and chi-square tests were then undertaken to summarize the profile of the stakeholders and their opinions and to find statistically significant correlations between variables.

\section{Findings}

\subsection{Stakeholder profile}

Stakeholders in Prince Edward County belong to various types of organizations and $31 \%$ of them operate a secondary business from their main business location (see Table 1). The highest number of respondents in the county was found to be in accommodation $(21 \%)$, non-tourism business such as retail, media, and service firms (19\%), and gallery, craft, gift or clothing shop (18\%). The secondary business that one third of respondents operate followed a similar pattern; accommodation, non-tourism business, and gallery, craft, gift or clothing shop totalling nearly $70 \%$. A noticeable secondary business was tour provider/attraction (11\%) and food or beverage services/restaurants (14\%) while this was only $3 \%$ and $9 \%$ respectively in the case of the primary business.

The majority of respondents have been operating their business for more than 10 years $(59 \%)$ and living in the county for more than 10 years $(65 \%)$ as seen in Table 2 . Approximately $30 \%$ were relatively new businesses (less than 5 years) and over $20 \%$ moved to the county recently (less than 5 years), which reflects that the number of businesses and residents is growing in the county. Respondents were also asked how many months per year their business stays open to their clients to identify whether their businesses were seasonal (see Table 3). The majority $(71 \%)$ were found to stay open to their clients for all year round, however, $17 \%$ of 
them reported that they open for 7 to 10 months, and $8 \%$ of them open for only 4 to 6 months per year.

Table 1. Type of Organization

\begin{tabular}{|c|c|c|}
\hline & Primary business $(\%)$ & Secondary business $(\%)$ \\
\hline Accommodation & 20.8 & 24.3 \\
\hline Non-Tourism business & 19.2 & 24.3 \\
\hline Gallery, Craft, Gift or Clothing Shop & 18.3 & 18.9 \\
\hline Agriculture & 12.5 & 8.1 \\
\hline Food or Beverage services/Restaurants & 9.2 & 13.5 \\
\hline Winery/Cider brewer & 8.3 & - \\
\hline Marketing/Industry Association & 4.2 & - \\
\hline Tour provider/Attractions & 3.3 & 10.8 \\
\hline $\mathrm{NGO}$ & 2.5 & - \\
\hline Government & 1.7 & - \\
\hline Total & 100 & 100 \\
\hline
\end{tabular}

$n=120$ for primary business

$n=37$ for secondary business

Table 2. Duration of Business Operation and Residence

\begin{tabular}{lccc}
\hline & Duration of business operation (\%) & Duration of residence $(\%)$ \\
\hline Less than 1 year & 5.8 & 7.5 & \\
1 - 2 years & 5.0 & 1.7 & \\
3 - 5 years & 17.5 & 12.5 & \\
6-10 years & 12.5 & 13.3 & 100 \\
More than 10 years & 59.2 & 65.0 & \\
Total & & & \\
\hline
\end{tabular}

$n=120$

Table 3. Months of Business Operation

Less than one month 1-3 months 4-6 months 7-10 months All year round Total

\begin{tabular}{llllll}
$(\%)$ & $(\%)$ & $(\%)$ & $(\%)$ & $(\%)$ & $(\%)$ \\
\hline 0.8 & 3.3 & 8.3 & 16.7 & 70.8 & 100 \\
\hline
\end{tabular}

$n=120$

\subsection{Importance of tourism development}

To understand stakeholders perceptions about the development plans over the planning period to 2021 by the County of Prince Edward Official Plan (2006), respondents were asked how important they considered tourism in the future viability of the county. The majority of respondents felt that tourism is extremely important for the county (66\%) (See table 4). Next, 
respondents were asked to rate to what extent they agreed that tourism in the county is currently year-round and whether they felt that tourism should be further developed to become year-round using a 5-point raking scale ranging from "strongly disagree" to "strongly agree". Then a 5-point scale was aggregated to 3-point scale to see the contrast between disagree ( 1 or 2 out of 5 ) and agree ( 4 or 5 out of 5 ) as seen in Table 5 . While most respondents disagree that tourism is currently year-round in the county $(53 \%)$, the majority of them think that tourism should be further developed to become year-round $(70 \%)$. Differences in agreement on whether tourism should be further developed to become year-round arose when the responses were compared based on the type of organizations using the $\chi 2$ analysis (see

Table 6). Although most types of organization supported the idea that tourism should be developed to become year-round, some organization types, especially agriculture businesses and non-government organizations (NGOs) stated that they disagreed (as high as 67\%). This result shows that significant difference of opinion existed among stakeholders.

Table 4. Importance of tourism to the future viability of the county

\begin{tabular}{lr}
\hline & $(\%)$ \\
\hline Not important at all & 3.4 \\
Somewhat not important & 0.9 \\
Neutral & 7.8 \\
Somewhat important & 22.4 \\
Extremely important & 65.5 \\
Total & 100 \\
\hline
\end{tabular}

$n=116$

Table 5. Assessment of opinions regarding year-round tourism

Is Tourism Currently year-round?

$(\%)$
Should Tourism become year-round?

$(\%)$

\begin{tabular}{lcc}
\hline Disagree & 53.0 & 17.4 \\
Neutral & 19.1 & 12.2 \\
Agree & 27.8 & 70.4 \\
Total & 100 & 100 \\
\hline
\end{tabular}

$n=115$ 
Table 6. Opinions on tourism as a year-round industry

\begin{tabular}{|c|c|c|c|c|}
\hline \multirow[b]{2}{*}{ Type of organization } & \multicolumn{4}{|c|}{ Should tourism become year-round? } \\
\hline & Disagree $(\%)$ & Neutral $(\%)$ & Agree $(\%)$ & Total $(\%)$ \\
\hline Non-Tourism business & 9.1 & 18 & 73 & 100 \\
\hline Accommodation & 12.0 & 12 & 76 & 100 \\
\hline Tour provider/Attractions & 0.0 & 0 & 100 & 100 \\
\hline $\begin{array}{l}\text { Gallery, Craft, Gift or } \\
\text { Clothing Shop }\end{array}$ & 0.0 & 10 & 90 & 100 \\
\hline $\begin{array}{l}\text { Food or Beverage } \\
\text { services/Restaurants }\end{array}$ & 9.1 & 9 & 82 & 100 \\
\hline Winery/Cider brewer & 11.1 & 11 & 78 & 100 \\
\hline Agriculture & 66.7 & 7 & 27 & 100 \\
\hline Government & 0.0 & 100 & 0 & 100 \\
\hline $\begin{array}{l}\text { Marketing/Industry } \\
\text { Association }\end{array}$ & 20.0 & 0 & 80 & 100 \\
\hline NGO & 66.7 & 33 & 0 & 100 \\
\hline
\end{tabular}

Note: $n=115 ;$ Pearson $\chi^{2}$ (Monte Carlo) $=50.1 ; p<0.001$

Respondents were asked if they felt that the four pillars of the county's economy, as stated to be significant in the County of Prince Edward Official Plan, are important as an employment base and income source (See Table 7). Most respondents indicated that all four industries are important, especially agriculture and tourism which ranked over $90 \%$ ( 4 or 5 out of 5 ). This response illustrates that the stakeholders generally agree with the directions of the county's development that was planned by the Official Plan.

Table 7. Importance of the four industries to the PEC's economy

\begin{tabular}{lclll}
\hline & Not important & No opinion either way & Important & Total \\
& $(\%)$ & $(\%)$ & $(\%)$ & $(\%)$ \\
\hline Agriculture & 1.8 & 0.9 & 97.3 & 100 \\
Tourism & 3.5 & 1.8 & 94.7 & 100 \\
Commerce \& Industry & 11.5 & 8.0 & 80.5 & 100 \\
Arts, Culture, \& History & 8.0 & 8.0 & 84.1 & 100 \\
\hline
\end{tabular}

\subsection{Beneficial elements of tourism development}

Next, respondents were asked to rate elements that are important to develop tourism that benefit the county overall. These recommendations were extracted from the Official Plan, Growing the Creative-Rural Economy in Prince Edward County (2008) by the Department of Geography at Queen's University and Cultivating Rural Creativity (2009) by Ryerson University's Urban Planning Department. Overall, respondents agreed on all elements except 
for the development of new and upscale accommodation. For elements such as preserving and promoting nature, culture, historical attractions and developing agriculture, local food, and outdoor activities, over $90 \%$ of respondents stated that they were important ( 4 or 5 out of 5). For developing and promoting wineries, festivals, local artist fairs, and attractive transportation options, over $75 \%$ of respondents agreed that they are important elements of tourism development. However, respondents were split in opinion on developing new and upscale accommodation; only $53 \%$ of them think it is important ( 4 or 5 out of 5) while $30 \%$ think it s not important and 17\% were undecided (see Table 8).

Table 8. Elements that are important for tourism development

\begin{tabular}{|c|c|c|c|c|}
\hline & $\begin{array}{l}\text { Not important } \\
(\%)\end{array}$ & $\begin{array}{l}\text { No opinion either way } \\
(\%)\end{array}$ & $\begin{array}{l}\text { Important } \\
(\%)\end{array}$ & $\begin{array}{l}\text { Total } \\
(\%)\end{array}$ \\
\hline Preserve and promote nature & 0.0 & 3.6 & 96.4 & 100 \\
\hline Conserve and promote culture & 1.8 & 7.2 & 91.0 & 100 \\
\hline Promote historical attractions & 1.8 & 7.2 & 91.0 & 100 \\
\hline Develop and promote wineries & 9.9 & 9.0 & 81.1 & 100 \\
\hline $\begin{array}{l}\text { Develop and promote } \\
\text { agriculture }\end{array}$ & 0.0 & 5.4 & 94.6 & 100 \\
\hline $\begin{array}{l}\text { Develop and promote local } \\
\text { food }\end{array}$ & 0.9 & 3.6 & 95.5 & 100 \\
\hline $\begin{array}{l}\text { Develop and promote outdoor } \\
\text { activities }\end{array}$ & 0.0 & 7.2 & 92.8 & 100 \\
\hline $\begin{array}{l}\text { Develop new and upscale } \\
\text { accommodation }\end{array}$ & 29.7 & 17.1 & 53.2 & 100 \\
\hline $\begin{array}{l}\text { Develop attractive } \\
\text { transportation options }\end{array}$ & 9.9 & 14.4 & 75.7 & 100 \\
\hline Develop and promote festivals & 1.8 & 13.5 & 84.7 & 100 \\
\hline $\begin{array}{l}\text { Develop and promote local } \\
\text { artist fairs }\end{array}$ & 9.9 & 12.6 & 77.5 & 100 \\
\hline
\end{tabular}

$n=111$

This disagreement is also congruent with the answers for the next question which asks to what extent they agree that such resort developments should be encouraged to promote longer visitor stays and year-round tourism benefits (Table 9). Approximately $41 \%$ of stakeholders agreed that PEC should encourage more upscale resort developments. In contrast, $42 \%$ of them disagreed; this confirmed that there exists complete disagreement on the direction of tourism development. While there is no agreement on the development of upscale resorts, the majority of respondents agreed that such developments do not complement the historic rural character and charm of the county $(62 \%)$. Also, as seen in Table 10 , even those who agreed 
on more upscale accommodation development do not agree that such development complements the charm of the county (correlation $=.622, \mathrm{p}<0.01$ ). When those who stated that tourism is important for future viability ( $88 \%$ of respondents) and that tourism should become year-round ( $70 \%$ of respondents) were cross-tabulated with their opinion on encouraging more upscale accommodation (Table 11), stakeholders did not agree. This suggests that the county needs to search for a way to develop tourism with sustainability since tourism development is desired but should not risk its rural features.

Table 9. Development of upscale accommodation

\begin{tabular}{llll}
\hline & $\begin{array}{l}\text { Should the County encourage more } \\
\text { upscale resort developments? }(\%)\end{array}$ & $\begin{array}{l}\text { Do such resort developments } \\
\text { complement the historic rural character } \\
\text { of the County? }(\%)\end{array}$ & \\
\hline Disagree & 42.3 & 61.5 & \\
Neutral & 16.3 & 21.2 & 100 \\
Agree & 41.3 & 17.3 & \\
Total & 100 & & \\
\hline
\end{tabular}

$n=104$

Table 10. Cross Tabulation of Respondents who were in favour of resort development vs. character

Stated the County should Do such resort developments complement the historic rural encourage more upscale resort character of the County? (\%)

\begin{tabular}{lllll}
\multirow{2}{*}{ developments $(\%)$} & Disagree & Neutral & Agree & Total \\
\hline 41.3 & 27.9 & 32.6 & 39.5 & 100 \\
\hline
\end{tabular}

Note: $n=104$; Pearson $\chi^{2}($ Exact $)=50.4 ; p<0.001$

Table 11. Opinion on upscale resort developments

\begin{tabular}{|c|c|c|c|c|c|}
\hline & & \multicolumn{4}{|c|}{$\begin{array}{l}\text { Should the County encourage more upscale resort } \\
\text { developments? }(\%)\end{array}$} \\
\hline & & Disagree & Neutral & Agree & Total \\
\hline $\begin{array}{l}\text { Stated that tourism is important as } \\
\text { future viability }(\%)\end{array}$ & 87.9 & 37.0 & 17.4 & 45.7 & 100 \\
\hline $\begin{array}{l}\text { Stated that tourism should become } \\
\text { year-round }(\%)\end{array}$ & 70.4 & 29.3 & 16.0 & 54.7 & 100 \\
\hline
\end{tabular}

Note: Stated that tourism is important as future viability.

$n=116$; Pearson $\chi 2$ (Exact) $=12.5 ; \mathrm{p}<0.05$.

Stated that tourism should become year-round

$n=115$; Pearson $\chi^{2}$ (Exact) $=27 ; \mathrm{p}<0.01$.

4.4 Negative issues of tourism 
Respondents were then provided an open ended question to determine what they believed the county had done to address any issues resulting from tourism. Overall, most respondents did not believe enough had been done. The main responses from a cluster analysis outlined that little had been done and many were angry about such issues as demonstrated by respondent 43: "Nothing as far as I know, and if it has, it hasn't done enough to bring this to anyone's attention. The fact that the promotion of cheese-making was cancelled speaks volumes about the negative attitude of cash crop farmers and traditional dairy (cow) farmers towards the promotion of boutique manufacturing of marginal dairy (goat and sheep) farmers". Those that discussed initiatives mainly mentioned the council had held meetings, however, respondents did not feel these were satisfactory. As illustrated by respondent 41: "Meetings and more meetings - the County does not seem to have a plan, vision, philosophy regarding tourism development - so they have meetings." A few initiatives were mentioned by three respondents ( $6.3 \%$ of responses) such as improved signage to reduce traffic flow and that a noise policy was being considered.

Of the respondents who felt that negative issues had not been sufficiently addressed ( $71 \%$ of total responses), the main concern was over sustainability issues. Governance and policy, infrastructure and tourism development were the most discussed. Some respondents $(8 \%$ of total responses) also felt that the local government had not stood up to the provincial government when it came to the approval of wind turbines in the county. Although this is not a specific tourism issue, it relates to environmental opinions and overall policy development in the county. Respondent 101 summarized many respondents' comments: "The county has had many economic 'lives' and these days the business is tourism - so the wineries, food, festivals and agriculture are essential — as are history and the local environment — but without a strong policy that recognizes the importance of these matters, there is an inconsistency — where one hand doesn't seem to know what the other is doing." Additionally, respondents did not feel that the county had a strategic plan for the future development of tourism that addressed all sustainability elements. Year round employment, environmental protection and cost of living were mentioned. As respondent 66 noted: "The county is unique in Ontario in that it has no protections plans (see lake Simcoe), has no greenbelt areas, has no shore land management plans and no strategy for groundwater or surface water management despite the fact that agriculture, tourism and the wineries are all dependent on successful water management." From an infrastructure point of view, most comments addressed signage due to increased traffic congestion and many mentioned demolition of heritage buildings on Picton's main street.

Tourism, as mentioned earlier in responses, is an important industry in the county; however, not all are in agreement it is being appropriately governed. As respondent 95 notes, "There [is], [it] seems to me, no good reason to create plans to make tourism a viable/sustainable industry in the County in 2005 and then walk away from it in 2010. Municipal support and collaboration on new and revised projects must continue - tourism isn't a static industry."

After the comments were gathered through open-ended questions, stakeholders' opinions were asked to respond to a 5-point Likert-type scale question. Respondents were asked whether they felt that there was sufficient infrastructure development and communication 
related to tourism (see Table 12). In the County's Official Plan, there are four objectives mentioned in these areas. There was no agreement on the current status of tourism development among the respondents as presented in the table; the only agreement was that $47 \%$ of the respondents thought there was insufficient parking in the county.

Table 12. Current status of tourism development

\begin{tabular}{|c|c|c|c|c|}
\hline & $\begin{array}{l}\text { Disagree } \\
(\%)\end{array}$ & $\begin{array}{l}\text { Neutral } \\
(\%)\end{array}$ & $\begin{array}{l}\text { Agree } \\
(\%)\end{array}$ & $\begin{array}{l}\text { Total } \\
(\%)\end{array}$ \\
\hline There is sufficient parking & 47.1 & 17.3 & 35.6 & 100 \\
\hline $\begin{array}{l}\text { There is an adequate water supply system for } \\
\text { commercial use }\end{array}$ & 31.7 & 28.8 & 39.4 & 100 \\
\hline $\begin{array}{l}\text { There is an adequate sewage treatment system for } \\
\text { commercial use }\end{array}$ & 30.8 & 32.7 & 36.5 & 100 \\
\hline $\begin{array}{l}\text { There is active communication between tourist } \\
\text { operators, information centre, and agencies }\end{array}$ & 40.4 & 28.8 & 30.8 & 100 \\
\hline
\end{tabular}

\subsection{Ensuring a long term viable future for the county through tourism}

To find out what respondents think should happen to ensure a long term viable future for their business and community, an open-ended question was asked to solicit unbiased responses. Many stakeholders suggested the development and promotion of tourism should be continued in PEC to support the local economy, offer employment opportunity, and create year-round business for the shoulder and off seasons to reducing the negative impacts of seasonality. The majority also stated that the county should preserve its culture, history, and nature while attracting additional tourism. Some were concerned about abrupt over-development in tourism, suggesting slow and manageable growth with new policies for tourism. A high proportion of stakeholders (12\% of total responses) emphasized the necessity of long term, new, and integrated planning and economic and marketing strategies that can be sustainable and balance all of the factions of the community. Desire for the development of infrastructure was stated by many stakeholders as well; also, public transportation, high speed Internet, health care, public washrooms, and education system were discussed.

In addition to the suggestions for the direction of tourism development, $15 \%$ of total respondents also elaborated on issues about general government or current policy that affected the county. The most frequently discussed issue regarding recent policy was that of onshore wind turbine installation, which some feel negates the natural beauty and heritage of the region. The lack of a plan for sustainable development of the county's economy and the absence of the incorporation of its natural heritage value and residents' views into the Official Plan were also major concerns. Disagreement among stakeholders on community development plans was another major issue. Many ( $9 \%$ of total responses) stated that 
stakeholders need to share and agree on the same vision or plan; more inclusiveness and connectivity among them should be developed through improved working relationships.

Following the open-ended question, two Likert scale questions were asked to compare how stakeholders perceive the recommendations of the three plans: the Official Plan, Growing the Creative-Rural Economy in Prince Edward County (2008), and Cultivating the Rural Creativity (2009) (Table 13). While $82 \%$ of respondents thought tourism contributes to the agricultural industries, $67 \%$ of respondents felt that funds are better spent elsewhere than on tourism development. The respondents did not agree on public transportation, land and labour use by tourism, or natural resource consumption by tourism sections.

Table 13. Stakeholder's view on tourism development recommendations

\begin{tabular}{lllll}
\hline & $\begin{array}{l}\text { Disagree } \\
(\%)\end{array}$ & $\begin{array}{l}\text { Neutral } \\
(\%)\end{array}$ & $\begin{array}{l}\text { Agree } \\
(\%)\end{array}$ & $\begin{array}{l}\text { Total } \\
(\%)\end{array}$ \\
\hline $\begin{array}{l}\text { Funds are better spent on tourism development } \\
\text { Public Transportation should be developed }\end{array}$ & 67.0 & 21.4 & 11.7 & 100 \\
Tourism contributes to the agricultural industries & 35.0 & 15.5 & 49.5 & 100 \\
economically & 13.6 & 4.9 & 81.6 & 100 \\
Tourism development used prime agricultural land & 38.8 & 28.2 & 33.0 & 100 \\
Tourism development took away government funding & 46.6 & 35.9 & 17.5 & 100 \\
Tourism development took away labour from agriculture & 60.2 & 28.2 & 11.7 & 100 \\
Tourism development consumed natural resources & 36.9 & 32.0 & 31.1 & 100 \\
\hline
\end{tabular}
$n=103$

\section{Discussion}

Often in tourism development, policies have become more important at both the national and regional levels (Kumral \& Önder, 2009), however, this case study illustrates that issues at the local level must be addressed if all stakeholders are to buy into current development. The assessment of stakeholders who will be most affected by tourism development and the inclusion of their views in tourism planning are politically legitimate and will help to reduce the cost of resolving future conflicts. Stakeholders will add value to tourism development by contributing their knowledge and experience and the resulting policy is likely more acceptable (Medeiros de Araujo \& Bramwell, 1999) and sustainable (Simpson, 2001). For these reasons, this paper assessed stakeholders' views on tourism policy and development in Prince Edward County.

The findings from the study suggest that the majority of stakeholders agree with the importance of tourism development but many feel there are issues not being addressed by the county and are unhappy with current direction of tourism development status. The same was found in the stakeholder interviews and tourism planning study conducted at Pamukkale in Turkey (Yuksel, et al., 1999), where the local people and organizations felt that there had been inadequate consultation with them. The challenges Prince Edward County faces include demographic challenges, seasonality, infrastructure, tourism product, and nature and local 
ecosystems. With regards to sustaining livelihoods, different stakeholders have different views about what is important for development and long term sustainability for the region.

One of the concerns from this study is a demographic challenge since many people, particularly retirees, are migrating from metropolitan areas such as Toronto to PEC, changing the demographics in PEC. Demographic trends show that while there is moderate population growth, most of that growth will be concentrated among those who are 40 and older, with a subsequent decline in age groups $20-40$ by 2031 . This demographic change will contribute to a skilled labour shortage in the tourism sector because the labour pool will become limited in number and those educated in tourism (Cultivating Rural Creativity, 2009). Currently there is little stable work in the county and many residents work more than one job. That being said, there is a shortage in the labour pool. Wineries often have to import labour as there is a shortage or they cannot find locals who are willing to do the type of work required.

Another challenge is seasonality. Central concerns from community members include the immense seasonal changes in traffic, both on and off the roads, as the majority of PEC's visitors come between the months of June and September. During this peak season, the amount of waste and vehicular emissions from the influx of traffic increases, escalating the demand and competition for services and concerns of elevated crime rates. This results in uneven seasonal income for the residents and tourism businesses (PEC, 2008). Many residents do not have year-round employment.

The county's infrastructure has not been fully developed to accommodate both residents and tourists, creating another major challenge for sustainable growth. Public transit is not available within or to many areas within PEC, and amenities for the community such as recreational and parking facilities are not yet in place. The county recently launched a construction project for a new water pollution control plant and is processing the development proposal of a wind energy park within the county. The expansion of infrastructure is critical for this area to accommodate the future demands of tourists.

Edgell et al. (2008) outline that tourism can be economically viable for private companies and local communities while also being sensitive to community and social needs, however, "the connection of both the resources and the values of a community aid in the development and planning practices" (p. 195). Therefore, there must be a careful balance between meeting the needs of the host community and the needs of the industry and government. From this research, it seems that stakeholders do not communicate with each other and many do not feel like they are part of the process. With no agreement on the status of the county's development and the future direction of development, it will be difficult to achieve sustainability in terms of culture, history, resource use and nature. Society has generally not understood the need for sustainable development (Lane, 2009) and sustainable livelihoods require behavioural changes to be made by all stakeholders.

In order to attain a cohesive vision, a partnership approach where all stakeholders work together to achieve a common goal is needed. As the Official Community Plan is in need of updating, there is an opportunity for a collaborative partnership approach to tourism planning in the county. This study obtained a high response rate and people are very interested in the 
current and futures states of tourism development in PEC. The majority of respondents $(66 \%)$ agree that tourism is extremely important to the county and there is also consensus about what elements are important to tourism. Apart from the development of large scale resorts, most respondents were in agreement about the future needs of the county and what would be beneficial. The findings of this study are key as they demonstrate that there is unity in the county and therefore policy makers and the government could build upon this to form a future Official Community Plan which reflects the needs of different stakeholders while also considering the economic elements which must be considered overall.

If tourism is to continue to grow in the county, tourism product development is necessary to attract longer stays and increase tourism receipts in the county. The majority of visitors come for only day trips (Brain Trust Marketing \& Communications, 2005). This is partially because the range of tourist products does not sustain tourists' interest for more than one day; therefore, the county is not creating sufficient market demands. This implies a space for potential diversification in tourism products, however, sustainability elements must be considered for the long term viability of both jobs and natural and cultural resources. Therefore, a diversification strategy highlighting the unique aspects of the county is required. Protection as well as investment is required of the county's cultural attractions, provincial park, festivals and events, and unique tourist experience. This has been also outlined by a recent tourism competitiveness study which examines potential for further growth and competitiveness in tourism (The Ontario Tourism Competitiveness Study, 2009).

Although the central attraction for most visitors is nature-based, it appears that there is a need to improve environmental protection and planning standards in the county. The sudden growth in tourists in the summer months will have a great environmental impact, especially at Sandbanks Provincial Park. The consequence can be a threat of e-coli bacteria in the water and subsequent beach closures (Brain Trust Marketing \& Communications, 2005). Rising environmental consciousness can have negative impacts on the demand and cost of tourism products (The Ontario Tourism Competitiveness Study, 2009). As Prince Edward County is an island with a smaller population, individual stakeholder's opinions are even more important than densely populated areas and working with tourism and non-tourism businesses and communities will ensure a collaborative planning approach is undertaken to address tourism concerns. As "different stakeholders have different agendas, there is often a disconnect between ideal policy goals and achievable outcomes" (Dodds \& Butler, 2009: 47) working with all stakeholders to gain their insights is a valuable tool for future development of policy in Prince Edward County.

\section{Conclusion}

Prince Edward County recognizes the opportunity for tourism to grow further to be a significant economic and social contributor to the community. For tourism to become a viable tool for sustainable livelihoods in the county, it is necessary to develop plans and policies that take into consideration all stakeholders' views as well as work with these local stakeholders to inform and include them. Various key stakeholders in this study identified issues, concerns, and opportunities with respect to tourism development in the community from different 
perspectives which are wide reaching and inclusive of the four pillars of the economy in Prince Edward County.

\section{References}

Ainsley and Associates Limited. (2006). County of Prince Edward Official Plan. The County of Prince Edward Planning and Development Committee, Bellville

Brain Trust Marketing \& Communications. (2005). Premier ranked tourist destination report for Prince Edward County.

Bramwell, B. \& Sharman, A. (1999). Collaboration in local tourism policymaking. Annals of Tourism Research, 26(2), 392-415.

Cole, S. (2006). Information and empowerment: The keys to achieving sustainable tourism. Journal of Sustainable Tourism, 14(6), 629-644.

Dodds, R. (2007). Sustainable tourism and policy implementation: lessons from the case of Calviá, Spain. Current Issues in Tourism, 10(4), 296-322.

Dodds, R. \& Butler, R.W. (2009) Inaction more than action: Barriers to the implementation of sustainable tourism policies" in Gossling, S., Hall, M. \& Weaver, D.B (eds) Sustainable Tourism Futures. New York: Routledge. Pp. 43-57

Duim, R. \& Caalders, J. (2004). The margins of Texel. Journal of Sustainable Tourism, 12(5), 367-387.

Edgell, D. L., Allen, M. D., Smith, G., \& Swanson, J.R. (2008). Tourism policy and planning yesterday, today, and tomorrow. Boston: Elsevier Inc.

Graci, S. \& Dodds, R. (2010). Sustainable tourism in island destinations. London: Earthscan.

Gülcan,Y., Kustepeli,Y., \& Akgüngör, S. (2009). Public policies and development of the tourism industry in the Aegean region. European Planning Studies, 17(10), 1509-1523.

Kumral, N. \& Önder, A. Ö. (2009). Tourism, Regional Development and Public Policy: Introduction to the Special Issue. European Planning Studies, 17(10), 1441-1443

Lane, B. (2009) "Thirty years of Sustainable Tourism: Drivers, Progress, Problems - and the Future" in Gossling, S., Hall, M. \& Weaver, D.B (eds) Sustainable Tourism Futures. New York: Routledge. Pp19-32

Lim, C.C. \& Cooper, C. (2009). Beyond sustainability: optimizing island tourism development. International Journal of Tourism Research, 11(1), 89-103.

Lockhart, D.G. (1997) Islands and tourism: an overview. In: D.G. Lockhart and D. Drakakis-Smith (eds) Island Tourism - Trends and Perspectives. London: Pinter: pp 3-21.

Marcouiller, D.W. (1997). Toward integrative tourism planning in rural America. Journal of Planning Literature, 11(3), 337-357. 


\section{Macrothink}

Medeiros de Araujo,L. \& Bramwell, B. (1999). Stakeholder assessment and collaborative tourism planning: the case of Brazil's Costa Dourada Project. Journal of Sustainable Tourism, 7(3\&4), 356-378.

The Ontario Tourism Competitiveness Study (2009). Discovering Ontario: A Report on the Future of Tourism. Ministry of Tourism, Ontario.

Prince Edward County (2007). Quick Facts. Retrieved September 26, 2010 from http://www.pecounty.on.ca/county_overview/index.php

Prince Edward County (2008). Growing the creative-rural economy in Prince Edward County. Department of Geography, Queens University, Retrieved September 26, 2010 from

http://www.pecounty.on.ca/government/corporate_services/pdf/FinalReporttoPECGphy337.p df

Ryerson University and Prince Edward County Planning and Economic Development Department (2009) Cultivating Rural Creativity. Prince Edward County.

Simpson, K. (2001). Strategic planning and community involvement as contributors to sustainable tourism development. Current Issues in Tourism, 4(1), 3-41.

Theobald, W.F. (2005) Global Tourism. Burlington: Elsevier

World Travel and Tourism Council (2010). Travel \& Tourism economic impact: executive summary.

On

WWW

at http://www.wttc.org/bin/pdf/original_pdf_file/2010_exec_summary_final.pdf

Yuksel, F., Bramwell, B., \& Yuksel, A. (1999). Stakeholder interviews and tourism planning at Pamukkale, Turkey. Tourism management, 20(3), 351-360.

\section{Copyright Disclaimer}

Copyright reserved by the author(s).

This article is an open-access article distributed under the terms and conditions of the Creative Commons Attribution license (http://creativecommons.org/licenses/by/3.0/). 